\title{
On the Arts
}

\section{INTRODUCTION TO "NO MORE AWAY: TECHNO-ATTACHMENTS AND THE RELATIONAL FUTURE" BY CHRISTINA R. GRIFFIN Ph.D.}

I had the great pleasure of encountering Christina Griffin's paper first as a live presentation. The Henry James passages were read by our colleague Jay Swanson, whose warm measured baritone recalled to me Cyril Cusack's amazing narration of the 1970s BBC adaptation of The Golden Bowl. I say "amazing" because until that time, I had literally been unable to read James. Since then, in every line of anything James has written, I can hear Cyril Cusack's voice and phrasing, making it instantly readable ... and lovable.

Now here is her paper prepared for a reading audience, and it is no less remarkable. The contrast between the voices-Griffin's and James's-is particularly striking for the difference in tempo. In the James passages, as you give yourself over to the leisurely pacing of the phrases, time seems to slow down. And this is Griffin's point: to call our attention to the speededup density of everyday life to which we have become habituated. As she struggles to come to terms with how altered from her own is this period of her daughters' coming to maturity, she invites us to treasure again with her the experiences we may have been fortunate to have gathered of a quieter pace, and to restore them to possibility in the now. 